\title{
Arbitrators Hearing Grievances Under the National Football League's Collective Bargaining Agreement Should Require Grievances to be Timely Filed
}

\author{
AARON J. SOBASKI \\ Sheppard, Mullin, Richter \& Hampton LLP
}

Perhaps more so than in any other sport, timing is crucial in the National Football League ("NFL"). A linebacker must time his blitz perfectly to avoid the blockers, wide receivers and quarterbacks must practice for months in the off-season to perfect the timing of pass, and, once the games start, the offense must proceed quickly or risk being penalized for "delay of the game." Timing is also incredibly important off the field in the NFL, as players and teams risk being penalized for "delay of game" if they do not adhere to the deadlines set forth in the NFL Collective Bargaining Agreement ("NFL CBA). ${ }^{1}$

This paper analyzes the deadlines, found in Articles IX and X of the NFL $\mathrm{CBA}$, that govern player and team grievances and analyzes the arbitrators' interpretations of these deadlines, concluding that arbitrators who interpret the NFL CBA should strictly construe these deadlines. Part I provides an overview of federal labor policies, emphasizing the arbitration requirements in collective bargaining agreements and proper role of the court in labor disputes. Part II briefly examines timeliness issues and the general policy behind statutes of limitations. Part III discusses the NFL CBA and its player grievance provisions. Part IV analyzes key arbitration decisions that have interpreted the time limits in the NFL CBA. Finally, Part V argues that arbitrators should strictly construe the time limits found in the NFL CBA. 


\section{FEDERAL LABOR POLICY}

With the National Labor Relations Act in 1935, the United States Congress established collective bargaining as the preferred method for settling workplace disputes. ${ }^{2}$ Twelve years later, Congress enacted Section 301 of the Labor Management Relations Act, which gave the federal courts jurisdiction to enforce collective bargaining agreements. ${ }^{3}$ The purpose of these acts was to promote commerce through industrial peace, and Congress hoped the new laws would accomplish this goal by prescribing the rights of employees and employers and outlining the procedures that each group should follow to protect their prescribed rights. ${ }^{4}$ The Supreme Court has interpreted these statutes on numerous occasions and, in doing so, has clarified the role of the judiciary in the collective bargaining process.

\section{A. Defining the Role of the Judiciary}

Courts have consistently ruled that when a collective bargaining agreement is involved the role of the judiciary is limited to deciding whether a case should go to arbitration, as this best reflects legislative intent. In United Steelworkers of America v. Warrior \& Gulf Navigation Co., the Supreme Court thoroughly explained the purpose behind the federal labor policy and the limited role of the judiciary in effectuating that policy. ${ }^{5}$ The Court found that Congress wanted to "promote industrial stabilization through the collective bargaining agreement," which becomes a "new common law" that governs the disputes that inevitably arise in industrial relationships. ${ }^{6}$ Stated simply, a collective bargaining agreement is a mutually agreed upon contractual system of self-government. ${ }^{7}$ At the "heart" of this system is the grievance process whereby the inevitable labor disputes are settled through arbitration, not the courts. $^{8}$ The quid pro quo for management's agreement to an arbitration provision is the labor union's agreement not to strike. ${ }^{9}$ These two provisions

2. 29 U.S.C. $\S 151$ (2002).

3. Id. $\S 185$.

4. Id. $\S \S 141 \& 151$.

5. Steelworkers v. Warrior \& Gulf Navigation Co., 363 U.S. 574, 578 (1960).

6. Id.

7. Id.

8. Id.

9. Id. 
work hand in hand to advance the common goal of management and laboruninterrupted production. ${ }^{10}$

Labor arbitrators not only draw upon the collective bargaining agreement itself, but also upon the "common law" of the particular industry that has developed through past arbitration decisions. ${ }^{11}$ These arbitrators are chosen because, with their particular knowledge of an industry, they are able to factor in the past interpretations of the collective bargaining agreement and are better able to understand how their decision will affect intangibles such as productivity and morale. ${ }^{12}$ Their informed decisions address the parties' "specialized needs" and are the result of the process favored by Congress. ${ }^{13}$ Therefore, any "judicial inquiry" should be limited to whether the parties agreed to arbitrate a particular issue, and any doubts that a court may have "should be resolved in favor of [arbitration]". ${ }^{14}$ If a court decides the issue is to be arbitrated, then the substantive issues are left to the arbitrator. ${ }^{15}$

\section{B. Further Defining the Limited Jurisdiction of the Judiciary}

Four years after Warrior \& Gulf, the Supreme Court further defined the limited scope of the judiciary's role in this system. In John Wiley \& Sons, Inc. v. Livingston, the Court held that the limitation extended to procedural as well as substantive questions. ${ }^{16}$ "Once it is determined... that the parties are obligated to submit the subject matter of a dispute to arbitration, 'procedural' questions which grow out of the dispute and bear on its final disposition should be left for the arbitrator."17 Since "procedural prerequisites to arbitration do not arise in a vacuum ... neither logic nor considerations of policy," allow courts to treat "substantive" and "procedural" issues differently. ${ }^{18}$ Thus, disputes regarding the grievance procedures of a particular collective bargaining agreement (such as time limits) are for arbitrators, not the courts, to decide. ${ }^{19}$

10. Steelworkers, 363 U.S. at 582.

11. Id.

12. Id.

13. Id.

14. Id.

15. Steelworkers, 363 U.S. at 582.

16. John Wiley \& Sons, Inc. v. Livingston, 376 U.S. 543, 557 (1964).

17. Id.

18. Id.

19. Although the vast majority of arbitrability cases are decided in favor of requiring arbitration the Supreme Court has held that some situations require judicial intervention. Charles B. Craver, 


\section{Limits on the Power of the Labor Arbitrator}

Although arbitrators are given broad powers to decide labor disputes, their power is not without limits. The arbitrator is a product of the collective bargaining agreement between the parties and thus, only derives power from the collective bargaining agreement itself. ${ }^{20}$ It follows, therefore, that the arbitrator's power is limited to interpreting the parties' bargained contractual rights. $^{21}$ The arbitrator should not "dispense his own brand of industrial justice. He may look for guidance from many sources, yet his award is legitimate only so long as it draws its essence from the collective bargaining agreement." 22 However, courts generally review arbitrators' decisions with great discretion; so long as the decision arguably is based upon the contract, courts are reluctant to overturn it, as courts "have no business overruling" a decision simply because a judge's interpretation differs from the arbitrator. ${ }^{23}$ The parties bargained for the arbitrator's decision, and the "federal policy of settling labor disputes through arbitration would be undermined if courts had the final say on the merits of the awards." 24

\section{TIMELINESS}

Arbitrators often have to decide procedural issues such as time limits before they can begin to decide substantive issues. Since Roman times, time limits for enforcing legal rights have been a part of legal systems; statutes of limitations have a long history in English law and came with the Colonial settlers to the United States. ${ }^{25}$ The United States has recognized the continued

Symposium on Labor Arbitration Thirty Years after the Steelworkers Trilogy: Labor Arbitration as a Continuation of the Collective Bargaining Process, 66 CHI.-KENT. L. REV. 571 (1990). The first is where the employer's conduct "amounts to a repudiation" of the provisions of the collective bargaining agreement. Vaca et al v. Sipes, 386 US 171, 185 (1967). The second is when an employee has been wrongfully prevented from availing them self of the grievance remedies by the union. Both of these situations require that the employee first attempt to use the grievance procedures in the collective bargaining agreement. Once that attempt has proven futile, then the employee can seek redress from the courts. Republic Steel v. Maddox, 379 U.S. 650 (1965).

20. John Wiley \& Sons, Inc, 376 U.S. at 557.

21. Steelworkers v. Enterprise Wheel, 363 U.S. 593, 597 (1960).

22. Id.

23. Id. at 599 .

24. Id. at 596.

25. Developments in the Law-Statutes of Limitations, 63 HARV. L. REV. 1177 (1950). 
validity and importance of these limitations, ${ }^{26}$ which have become a "cardinal principle of modern law."27

The two principle rationales underlying the implementation of statutes of limitations are practicality and fairness. Statutes of limitations are "vital to the welfare of society" because they provide security and stability. ${ }^{28}$ They also provide parties with notice of when they must prosecute a right and when they can be free from the burden of the past. ${ }^{29}$ Time destroys evidence that may prove the truth of a matter: witnesses may die, memories may fade, and documents may be destroyed. Without some limitation on when a party can initiate an action, "it might be impossible to establish the truth." ${ }^{30}$

Time limits are only fully understood in the context of the particular statute or agreement in which they are found and reflect a value judgment about when it would be unjust to bring a claim. ${ }^{31}$ They strike a balance between the interest of protecting a valid claim and the inequities of allowing a stale one. ${ }^{32}$

Even though statutes of limitations may bar completely valid claims, they are "entitled the same respect" as other statutes and should not be "explained away." 33 As long as they give a party a reasonable time to assert its rights, they are Constitutionally valid and enforceable. ${ }^{34}$

Parties to a collective bargaining agreement establish "mandatory time limits for reasons best known to themselves." ${ }^{35}$ However, since a collective bargaining agreement creates the new common law governing labor disputes within a particular industry, it can be assumed that the time limits for initiating a grievance developed for the same reasons these limitations occur in other areas of law. In the labor context, having time limits promotes labor peace by ensuring a quick resolution of disputes without interrupting daily business. Expediency is a main reason why many labor agreements covering professions

26. See, e.g., Clementson v. Williams, 12 U.S. 72 (1814); Bell v. Morrison, 26 U.S. 351 (1828); Wood v. Carpenter, 101 U.S. 135 (1879); United States. v. Kubrick, 444 U.S. 111 (1979).

27. Campbell v. Haverhill, 155 U.S. 610 (1895).

28. Wood, 101 U.S. at 139

29. See, e.g., Kubrick, 444 U.S. at 117.

30. Riddlesbarger v. Hartford Ins. Co., 74 U.S. 386, 390 (1868).

31. Board of Regents v. Tomanio, 446 U.S. 478, 485 (1980).

32. Id.

33. Clementson, 12 U.S. at 73.

34. See, e.g., Campbell, 155 U.S. 615.

35. Joyce v. L.A. Rams (1980) (Stark, Arb.). 
from doctors to dockworkers have explicit time limitations on grievance filings. ${ }^{36}$

\section{THE NATIONAL FOOTBALL LEAGUE COLLECTIVE BARGAINING AGREEMENT}

Often hundreds of pages long and "extremely complicated and delicately balanced," collective bargaining agreements are the product of hundreds of hours of negotiations between labor and management, reflecting numerous compromises and tradeoffs. ${ }^{37}$ Therefore, it is difficult for people not intimately involved in the negotiations to discern why a specific time limit is necessary. Therefore, in analyzing how a particular industry such the NFL deals with timeliness, it is valuable to study the issue within the framework of the NFL.

The NFL is a collection of thirty-two individual organizations (teams) and has been in its current structure since merging with the rival American Football League in 1966. ${ }^{38}$ The first NFL collective bargaining agreement between the team owners (represented by the NFL Management Council ("NFLMC")), and the players (represented by the NFL Players Association ("NFLPA")) was signed in 1968 and the current CBA, signed in 1993, has been extended through $2008 .^{39}$ The NFL CBA is the product of "bona fide, arm's length collective bargaining" between the NFLMC and NFLPA. ${ }^{40}$

The only method for resolving disputes arising under the NFL CBA are through its grievance procedures as outlined in Articles IX and $\mathrm{X}^{41}$

36. Collective Bargaining Agreement Between COUnty of Marin And TeAmSter UNION, LOCAL 856, July 11, 1999 - July 3, 2004, Art. 7 (Social Workers); COLLECTIVE BARGAINING AgreEment BETWEen UnION OF AMERICAN PHysicians AND DENTISTS (Unit 11-AA) AND the CITY AND COUNTY OF SAN Francisco, July 1, 2001 - June 30, 2003, Art.I.F. (Doctors); PACIFIC COAST LONGSHORE CONTRACT DOCUMENT BETWEEN THE INTERNATIONAL LONGSHORE AND WAREhouse Union AND tHe PACIFIC MARITIME Association, July 1, 1999 - July 1, 2002, §17 (Dockworkers).

37. Stadium Financing and Franchise Relocation Act of 1999: Hearing on S. 952 Before the Senate Comm. on the Judiciary, 106th Cong. (June 22, 1999) (testimony of Gene Upshaw, Executive Director of the National Football League Players Association).

38. Although the merger occurred in 1966, the two players associations did not merge until 1970, the year when teams from the AFL and NFL began to play regular season games against each other. NATIONAL FOOTBALL LEAGUE PLAYERS ASSOCIATION PLAYBOOK (hereinafter NFLPA Playbook), § 2, NFLPA HISTORY (1995).

39. NFL CBA, supra note 1, at Introduction.

40. The NFLMC is the sole bargaining representative for the individual organizations. The NFLPA is the union for NFL players and is their sole bargaining representative. Id. at Preamble.

41. Id. Art. IX, § 1, Art. X, § 1. 
Grievances are divided into two categories, "injury" and "non-injury."42 Injury grievances are disputes that occur when a team terminates a player's contract at a time when the player believes he is unable to perform due to injury. ${ }^{43}$ All other disputes fall into the non-injury grievances category. ${ }^{44}$

\section{A. Article IX - Non-Injury Grievances}

Non-injury grievances are defined in Article IX, Section 1 of the NFL CBA and include any dispute regarding provisions of the NFL CBA, player contracts, or portions of the NFL Constitution or Bylaws that relate to conditions of employment for players. ${ }^{45}$ A player, the NFLPA, an individual team, or the NFLMC may initiate a non-injury grievance. ${ }^{46}$ To initiate such a grievance, the grievant must provide its opposition with written notice outlining the specific facts alleged by the grievant via certified mail or fax. ${ }^{47}$ The opposing side then has seven days to answer the non-injury grievance by admitting or denying the facts alleged. ${ }^{48}$

At this point, if the parties do not settle the dispute, an arbitrator will be appointed to preside over the grievance. ${ }^{49}$ Each side is entitled to limited discovery (exchange of relevant documents), and thereafter the arbitrator holds a hearing at which each side has an opportunity to present evidence. ${ }^{50}$ Upon completion of the hearing, the parties have a period of time during which they can present witnesses who were unavailable on the hearing date. ${ }^{51}$ The record is closed sixty days following the hearing date unless both parties mutually agree to expend the time-period. ${ }^{52}$ The parties may choose to file post-hearing briefs after the record is closed, provided that the dispute does not involve "non-suspension Club discipline where less than $\$ 25,000$ is at issue." ${ }^{33}$

42. Id.

43. Id. Art. X, § 1.

44. Id. Art. IX, $\S 1$.

45. Id.

46. Id. $\S 3$.

47. Id.

48. Id.

49. Id. $\S 4$.

50. Id. $\S \S 5,7$.

51. Id.

52. Id.

53. Id. 
If the parties submit post-hearing briefs, the arbitrator must issue a decision within thirty days of receiving the briefs. ${ }^{54}$ Provided that the decision does not exceed arbitrator's authority, the decision is the final resolution of the non-injury grievance. ${ }^{55}$

Aside from the procedures outlined above, the NFL CBA contains a limit on how long a party can wait before filing a non-injury grievance. ${ }^{56}$ Article IX, Section 2 states "a grievance must be initiated within forty-five days from the date of the occurrence or non-occurrence upon which the grievance is based, or within forty-five days from the date on which the facts of the matter became known or reasonably should have been known to the party initiating the grievance, whichever is later." 57 The parties can extend this time limit only through mutual written agreement. ${ }^{58}$

\section{B. Article X - Injury Grievances}

Injury grievances are limited to disputes regarding the physical condition of a player at the time his contract is terminated. ${ }^{59}$ The NFL's standard player contract provides that a team cannot release a player when he is physically unable to perform due to an injury sustained while performing under that contract. ${ }^{60}$ If a player believes that a team has violated this covenant, he (or the NFLPA on his behalf) can file an injury grievance against the team. ${ }^{61}$

The injury grievance process begins when either a player or the NFLPA presents the grievance in writing to the team with a copy sent to the NFLMC. ${ }^{62}$ The grievance must note the approximate date of the injury and its nature. ${ }^{63}$ The team then has seven days to answer the grievance and if denying the claim, must state the grounds for denial. ${ }^{64}$ Article X, Section 3 of the NFL CBA also lists numerous special defenses a team could assert, including: allegations that the player did not pass a pre-season physical, that the player

\section{Id. $\S 8$.}

55. Id. (requiring that arbitrators adhere to the negotiated terms of the NFL CBA and setting forth the type of awards that arbitrators can grant).
56. Id. § 2 .
57. Id.
58. Id. §9.
59. NFL CBA, supra note 1 , at Art. X, §1.
60. Id. at App. C, ๆๆ 9, 12-13.
61. Id. at Art. X, $\S 1$.
62. Id. $\S 2$.
63. Id.
64. Id. $\$ 3$. 
did not disclose his condition to the team during that physical, that the injury was not related to football, or that the injury occurred prior to signing the contract as acknowledged by a disclosure. ${ }^{65}$

After filing an injury grievance, a player must submit to a physical evaluation by a neutral physician within twenty days. ${ }^{66}$ If the parties cannot reach an agreement, they can appeal to an arbitrator within thirty days of receiving the neutral physician's report. ${ }^{67}$ After a period of limited discovery (exchange of relevant documents), the arbitrator holds a hearing at which both sides can present evidence. ${ }^{68}$ As with non-injury grievances, there is then a time period during which each side can present witnesses who were unavailable on the hearing date. ${ }^{69}$ The record closes sixty days following the hearing date unless mutually extended by the parties. ${ }^{70}$ Parties can submit post-hearing briefs up to sixty-five days after receipt of the transcript from the hearing, and the arbitrator must issue a decision within thirty days of receiving the post-hearing briefs. ${ }^{71}$ The decision is the final resolution of the injury grievance as long as the decision does not exceed the limited authority specified in Article X, Section 8. ${ }^{72}$ This clause requires that arbitrators not "add to, subtract from, or alter" the provisions of the NFL CBA. ${ }^{73}$

Like non-injury grievances, the NFL CBA also has a strict time limit on when a player may commence an injury grievance. Article X, Section 2 states that the player or NFLPA must submit the injury grievance "within twentyfive days from the date it became known or should have become known to the player that his contract had been terminated." 74 This deadline can be extended only through mutual agreement of the parties. ${ }^{75}$
65. Id.
66. Id. $\S 4$.
67. Id. $\S 6$.
68. Id. $\S \S 8,16$.
69. $I d . \S 8$.
70. $I d$.
71. Id.
72. Id.
73. Id.
74. $I d . \S 2$.
75. Id. § 1 . 


\section{DECISIONS INTERPRETING THE TIMELINESS PROVISIONS OF THE NFL CBA}

The time limits discussed above are integral parts of the NFL CBA grievance procedures, and many grievances have been decided based upon the issue of timeliness alone. ${ }^{76}$ While arbitrators are "loath" to decide grievances on procedural grounds, procedural requirements "do not take secondary status to the merits of the case."77 They are bargained for provisions that have changed over time with each new CBA. ${ }^{78}$ If the time limits were not important, they either would not be in the agreement or they would contain suggestive language such as "should" or "as soon as possible" instead of strict language such as "must" and specific time requirements. ${ }^{79}$ The parties know best why the specific time limits are in the NFL CBA, and the arbitrators lack the authority to substitute their own personal judgment for what time period is most fair. ${ }^{80}$

Joyce v. L.A. Rams is illustrative of this principle that procedural issues are not secondary to substantive ones. Joyce, a punter for the Rams, sprained his ankle during the 1978 training camp. ${ }^{81}$ A few weeks after his injury, before Joyce felt that he was healed, the Rams cut him in order to give another punter a chance to make the team. ${ }^{82}$ However, Coach George Allen told Joyce he might get a second chance if the new punter did not perform well. ${ }^{83}$ Joyce waited but never received a call from the Rams and thereafter filed his injury grievance. ${ }^{84}$ Arbitrator Arthur Stark dismissed the grievance without even considering the merits of the claim because Joyce filed his grievance twelve

76. See, e.g., Peterson v. Tampa Bay Buccaneers (1978) (Searce, Arb.); Joyce v. L.A. Rams (1980) (Stark, Arb.); Churchman v. San Francisco 49ers (1985) (Fisher, Arb.); Ridley v. Los Angeles Raiders (1996) (Stark, Arb.); New Orleans Saints v. Gumina (2002) (Wittenberg, Arb.).

77. Joyce v. L.A. Rams (1980) (Stark, Arb.), at 7.

78. National Football league Collective Bargaining Agreement (1977), Arts. VII, IX (containing a 60 day time limit for initiating a non-injury grievance and a 20 day limit for injury grievances); NAtional FoOtBall LeAgue Collective Bargaining AgreEment (1982), Arts.VII, IX (containing a 45 day time limit for non-injury grievances and a 20 day limit for injury grievances); and NAtional FoOtBall LeAgue COLleCtive BARGAining AgreEMENT 1993-2000, Arts. IX, X (containing a 45 day time limit for non-injury grievances and a 25 day limit for injury grievances).

79. Joyce v. L.A. Rams (1980) (Stark, Arb.), at 7.

80. Id. at 6; See also NFL CBA, supra note 1, at Art. IX, § 8 \& Art. X, § 8 .

81. Joyce v. L.A. Rams (1980) (Stark, Arb.), at 2.

82. Id. at 3 .

83. Id.

84. Id. 
days after the time limit had expired. ${ }^{85}$ While Joyce might have had a valid claim, Stark recognized the importance of adhering to the strict time limits set forth in the NFL CBA.

Although both sides are aware of the time limits in the CBA, and aware that they do not take a backseat to the merits of a claim, grievances are still filed after the window for filing has passed. ${ }^{86}$ Therefore to be successful, parties must find a way to circumvent the limits if they file past the deadline. Miscommunications, lawsuits, a player's attempt to sign with another team, and even wrong home addresses are a few examples of why grievances are untimely filed. ${ }^{87}$ The arbitrators' decisions in these grievances have become the case law that guides the parties in subsequent grievances, and although arbitrators are not bound by the previous decisions, past decisions are persuasive authority, which are considered when making a decision. Thus, analyzing the holdings of these decisions provides clarity regarding how the time limits in the NFL CBA are enforced.

\section{A. Lack of Prejudice}

One way in which parties have attempted to circumvent the deadlines is to claim that the defending party is not prejudiced by the delay. The NFLPA employed this argument in Joyce to no avail. ${ }^{88}$ The "parties carefully negotiated" the period for filing grievances, and the arbitrator lacks the power to "interpret those time requirements in terms of prejudice." 89 As another arbitrator had earlier noted, the terms of the NFL CBA express the

85. Id. at 7 .

86. It can be assumed that the teams, the NFLMC, and the NFLPA are aware of the time limits found in Articles IX and X, due to their familiarity with the NFL CBA. However, players who are new to the league may not be aware of the time limits. Therefore, a player's NFLPA certified agent and the NFLPA take steps to educate the players regarding their rights. One way in which NFLPA does this is by distributing a "Playbook" to players that outlines their rights. This playbook outlines the grievance procedures and clearly and repeatedly states the time limits for instituting a grievance. NFLPA Playbook, supra note 38 , at $3-5,7,9$. The NFLPA official website also explains the grievance process and notes the time limits. National Football Legaue Players Association, Frequently Asked Questions, at http://www.nflpa.org:3005/media/main.asp?subPage=FAQ (last visited Aug. 11, 2005).

87. See, e.g., Welborne v. Minnesota Vikings (1995) (Starks, Arb.); Lyons v. Green Bay Packers (1980) (Stark, Arb.); Dryer v. Los Angeles Rams (1988) (Kagel, Arb.); Ridley v. Los Angeles Raiders (1996) (Stark, Arb.).

88. Id.

89. Id. 
"expectations and commitments of one party to another."90 If specific time limits were not important, they "assuredly would not have been included." 11

\section{B. Ignorance of the Time Limits}

The excuse of ignorance of the NFL CBA time limits has also been pursued, with unsuccessful results. ${ }^{92}$ In Churchman v. San Francisco 49 ers, Churchman, the team's former starting strong safety, argued that his grievance should not be time-barred because he did not know about the limitations period. ${ }^{93}$ At the time of his release at the start of the 1982 season, Churchman had been battling a recurring knee injury and had been considering retirement. ${ }^{94} \mathrm{He}$ waited and did not file his injury grievance until January 5, 1983, well after the deadline.95 Arbitrator Fischer held Churchman's ignorance of the time limits could not overcome an untimely filing. ${ }^{96}$

In order to utilize an "ignorance defense," a party would have to prove not only his ignorance of the time limit but also that he had no means through which to acquire that knowledge. ${ }^{97}$ It would be impossible for a player or team to prove so, as the time limits are clearly stated in the NFL CBA. ${ }^{98}$ Further, the teams' and players' bargaining representatives, the NFLPA and NFLMC, explicitly bargained for them, and since those two groups are integral parts of the grievance process, it can be readily assumed they are fully aware of the specific time limits. ${ }^{99}$ Thus, either on their own or through their respective bargaining representatives, a player or team can easily become aware of the time limits. ${ }^{100}$ Therefore, ignorance of the time limits is not a defense to an untimely filing. ${ }^{101}$

\footnotetext{
90. Peterson v. Tampa Bay Buccaneers at 19 (1978) (Searce, Arb.).

91. Id.

92. See, e.g. Churchman v. San Francisco 49ers (1985) (Fisher, Arb.).

93. Id. at 2 .

94. Id.

95. Id.

96. Id. at 5 .

97. Id.

98. Id.

99. $I d$ at 8 .

100. Id at 5 .

101. Id.
} 


\section{Pursuing Other Legal Action}

Pursuing a claim in a court of law instead of through the grievance machinery also will not exempt a party from the time limits found in the NFL CBA. ${ }^{102}$ In 1981 Fred Dryer, a defensive lineman for the Los Angeles Rams, filed a breach of contract lawsuit against the team in California state court. ${ }^{103}$ Dryer, who gained fame after his football career as the title character in the television series "Hunter", claimed the team wrongfully terminated him in violation of a "no-cut" clause in his contract. ${ }^{104}$ The team argued that they had a right to cut him and additionally contended that his claim was covered by the NFL CBA and therefore, must be arbitrated under its grievance procedures. ${ }^{105}$ Dryer's case made its way to the California Supreme Court, which held that arbitration was required under the NFL CBA. ${ }^{106}$

Thereafter, Dryer filed a grievance in March of $1986 .{ }^{107}$ He claimed his grievance was timely because his state court lawsuit was filed within the time limits of the NFL CBA, and the Rams and NFLMC were sent a letter at that time enclosing a copy of the complaint in that suit. ${ }^{108}$ Arbitrator Kagel disagreed and held that the letter did not initiate a grievance, as it stated that Dryer did not have to arbitrate the issue. ${ }^{109}$ Thus, the grievance was timebarred since the actual filing was well over the time limits of the NFL CBA. ${ }^{110}$

\section{Expired Collective Bargaining Agreement}

Even if the NFL CBA has expired, grievances still must be filed within the designated time limits. ${ }^{111}$ Federal law usually requires that parties to a labor contract continue to use the grievance procedures outlined in that contract even if the dispute arises after the agreement has expired. ${ }^{12}$ This policy effectuates the parties' expectations and intent as expressed by the

102. Dryer v. Los Angeles Rams (1988) (Kagel, Arb.).

103. Id. at 7 .

104. Id. at 11 .

105. Dryer v. Los Angeles Rams, 40 Cal. 3d 406, 409 (1985).

106. Id. at 418 .

107. Dryer v. Los Angeles Rams (1988) (Kagel, Arb.), at 7.

108. Id. at 8 .

109. Id.

110. Id.

111. Brown v. Los Angeles Raiders (1995) (Volz, Arb.).

112. Nolde Bros. Inc. v. Local No. 358, 430 U.S. 243 (1976). 
agreement. ${ }^{113}$ However, the NFL does not rely on federal policy and Supreme Court decisions alone to ensure that arbitration will be used to settle disputes after the expiration of the CBA. Paragraph 13 of the NFL standard player contract explains the procedures governing an injury grievance that arises after the expiration of the NFL CBA. ${ }^{114}$ This paragraph requires the player to submit to a physical by the physician of his choice within sixty days of the examination by the team doctor. ${ }^{115}$ It also requires players to submit their grievance to binding arbitration within a "reasonable time."116

The aforementioned standard contract provision is consistent with the procedures governing injury grievances in the NFL CBA. Time is especially important with injury grievances since the central issue is the health of the player at the time he is released. ${ }^{117}$ "Early and independent" medical evaluation is crucial to determining if the player was "physically incapable of playing NFL level football" when released. ${ }^{118}$ Therefore, undue delay in submitting to a physical or filing of a grievance can cast into doubt the validity of the claim.

Brown v. Los Angeles Raiders is an example of this issue. ${ }^{119}$ The NFL CBA had expired when, during the 1992 training camp, Brown sprained a knee ligament during practice. ${ }^{120}$ The Raiders cut the former world record holding sprinter from the team three weeks later, but Brown waited seventytwo days after his release to file his grievance. ${ }^{121}$ Since his physical health at the time he was cut was in dispute, his delay in filing, which led to a delay in physical examination by an independent physician, cast doubt over his claim. ${ }^{122}$ As a result, he lost his injury grievance on timeliness grounds, despite the fact that the NFL CBA had expired. ${ }^{123}$

113. Id. at 254 .

114. NFL CBA, supra note 1, at App. C, ๆ 13.

115. Id.

116. Id.

117. Brown v. Los Angeles Raiders (1995) (Volz, Arb.).

118. Id. at 21 .

119. Id. at 22 .

120. Id. at 5-6.

121. Id. at 5-6, 16 .

122. Id. at 22 .

123. Id. 


\section{E. Changing the Type of Grievance}

If a party files a non-injury grievance and subsequently changes the status of the grievance to an injury grievance, or vice versa, the grievance is time barred if the second grievance was not filed within the requisite time period. ${ }^{124}$ In Peterson v. Tampa Bay Buccaneers, Peterson filed an injury grievance after disagreeing with the team's doctor that he was healthy when released during the 1977 training camp. ${ }^{125}$ However, while working on the grievance, the NFLPA discovered that Peterson should have filed a non-injury grievance once the team failed to pay because he had a clause in his contract guaranteeing him certain payments if injured while playing. ${ }^{126}$ The NFLPA contacted the team and expressed a desire to switch the status of the grievance. $^{127}$ The Buccaneers countered that the new non-injury grievance was time-barred. ${ }^{128}$

The NFLPA claimed that the original injury grievance was timely filed and that this was simply "redirecting" the grievance. ${ }^{129}$ Arbitrator Scearce disagreed, holding that the two grievance procedures "are distinct and separate and, as such, are expected to be implemented independently." 130 He reasoned that if a party could change grievance types at any time, without regard to the time limits of each specific procedure, it would frustrate the "expectations and commitments" of the CBA. ${ }^{131}$ Thus, if a party wants to switch grievance types, it must be sure to do so within the specified time limits of the grievance procedure to which it wishes to switch.

\section{F. When does the clock start?}

Perhaps the most contentious issue involving timeliness under the NFL $\mathrm{CBA}$ is when the time limit begins to run, and as a result, numerous cases have dealt with this specific question. ${ }^{132}$ The parties attempted to address this

124. See, e.g., Peterson v. Tampa Bay Buccaneers (1978) (Searce, Arb.).

125. Id. at 6 .

126. Id. at 8 .

127. $I d$.

128. Id.

129. Id.

130. $I d$.

131. Id.

132. See, e.g., Lyons v. Green Bay Packers (1980) (Stark, Arb.); Davis v. Arizona Cardinals (1996) (Kagel, Arb.); Ridley v. Los Angeles Raiders (1996) (Stark, Arb.); Smith v. Los Angeles Raiders (1995) (Jones, Arb.). 
question directly in the NFL CBA. ${ }^{133}$ The clock starts running for a noninjury grievance on the later of either the date of the occurrence or non-occurrence that gives rise to the grievance or on the date when the facts of the matter reasonably should have been known to the parties, and for an injury grievance, the clock starts when the player knows or should know their contract has been terminated. ${ }^{134}$ Although this language may seem straightforward, the parties have found it anything but.

\section{When should a player reasonably know he has been terminated?}

Only when a player knows, or reasonably should know, that his contract has been terminated, will the clock on his injury grievance begin to run; however, various circumstances can put the exact date of a player's contract termination at issue. Before he is officially released from his contract, a player's team places him on "waivers" by filing the appropriate documents with the league front office. ${ }^{135}$ If, after twenty-four hours, no other team has claimed the player's contract, his contract is terminated, and he is free to negotiate a new contract. ${ }^{136}$ Once the player is terminated, the team must provide him with an official notice either in person or by certified mail. ${ }^{137}$

Since the clock for an injury grievance begins to run as soon as the player knows, or reasonably should have known, that his contract has been terminated, it may begin to run before he ever receives official notice. ${ }^{138} \mathrm{~A}$ player who is cut in person and then goes on vacation and does not receive the team's official notice of termination until returning home some time later, may try to claim that the clock should not start to run until he receives the official notice in the mail. ${ }^{139}$ Former Los Angeles Raiders safety, Lester Ridley, tried this defense to untimeliness. ${ }^{140}$ After he was released in 1994, he went home for a few days before traveling to visit family and did not receive his official notice until returning home after his trip. ${ }^{141}$ Ridley argued that the time period for filing his grievance should not have commenced until after he received official notice from the team. Arbitrator Stark held that although the NFL

\footnotetext{
133. NFL CBA, supra note 1 , at Art. IX, $\S 2$ \& Art. X, $\S 2$.

134. Id. Art. IX, § 2 \& Art. X, § 2.

135. Id. Art. XXII.

136. National Football League Constitution, Art. XVIII.

137. Id.

138. Ridley v. Los Angeles Raiders at 4 (1996) (Stark, Arb.).

139. Id. at 9 .

140. Id.

141. Id. at 5 .
} 
CBA does require written notice of termination, the clock does not wait to start ticking until the player receives that notice. ${ }^{142}$ Otherwise a grieving player could circumvent the time limit simply by not returning home to his official mailing address until he wanted to file a grievance. ${ }^{143}$

However, sometimes team conduct confuses a player as to when he has been terminated. ${ }^{144}$ For example, during the 1977 pre-season, a Packers' coach told offensive guard Thomas Lyons that he was going to be cut, but Lyons protested that since he was injured, the team could not terminate his contract. $^{145}$ Thereafter, the Packers paid for Lyons to consult a doctor in his hometown of Denver. ${ }^{146}$ While he was in Denver, without notifying him verbally, they sent an official letter of termination to his Denver house. ${ }^{147}$ The letter was delayed, and when Lyons finally received it, his injury grievance would have been time barred if the clock had begun to run when he first spoke with his coach. ${ }^{148}$ Arbitrator Stark held the team's actions, in agreeing to pay for Lyons to travel to see a doctor in Denver, coupled with the Packers' silence during subsequent conversations with the player made it reasonable for Lyons to assume he was still employed until he received the official notice in the mail. ${ }^{149}$

Circumstances have also arisen where a player knows that his contract has been terminated but does not know that he is injured. As previously noted, the termination date is essential because it starts the countdown for filing injury grievances, and the countdown is not halted unless agreed to by the parties. ${ }^{150}$ Thus, it is possible that a player might not discover that he is injured or might not discover the full extent of his injury until after the expiration of the grievance period, rendering his claim time-barred.

In Welborne v. Minnesota Vikings, Arbitrator Stark held that an injury grievance was time-barred even though the player did not discover the full extent of his injury until after the grievance period had passed. ${ }^{151}$ Sullivan "Tripp" Welborne III, a former All-American at the University of Michigan,

\author{
142. Id. \\ 143. Id. \\ 144. Lyons v. Green Bay Packers (1980) (Stark, Arb.). \\ 145. Id. at 4 . \\ 146. Id. \\ 147. Id. \\ 148. Id. at 6 . \\ 149. Id. at 7 . \\ 150. NFL CBA, supra note 1, Art. X, $\S \S 1,2$. \\ 151. Welborne v. Minnesota Vikings (1995) (Starks, Arb.)
}


claimed that the Vikings' doctor misled him regarding the extent of a knee injury he sustained in 1992 and aggravated during the 1993 training camp. ${ }^{152}$ He claimed that since the team doctor said his knee was healthy enough to play, the clock should not have started until a subsequent examination proved otherwise. ${ }^{153}$ Arbitrator Stark dismissed his contention because it "would turn the injury grievance procedure upside down."154 The key to the injury grievance procedure is the health of the player at the time of release. ${ }^{155}$ If players could wait and file a claim months later, there would be no reliable way to determine their health at the time. ${ }^{156}$ Thus, the clock starts ticking once the player knows that he is cut, not once he knows that he is hurt. Subsequent decisions have followed this reasoning. ${ }^{157}$

\section{What was the event that gave rise to grievance?}

This question may seem simple, but NFL grievance history has shown it can be quite complicated. Non-injury grievances often involve payments made or not made to a player either under that player's contract or provisions of the NFL CBA, including negotiated contract bonuses and injury protection benefits. ${ }^{158}$ Bonus payments can be for things such as making the team, working out, or achieving particular statistical goals. ${ }^{159}$ Injury protection gives players who are injured in one season, and unable to play the following season due to that injury, a portion of their salary for that following season. ${ }^{160}$ In both situations, since the clock begins to run at the occurrence or nonoccurrence of some event, the key is determining what that event is. ${ }^{161}$

In disputes regarding contract bonuses, both management and players have contended that the clock should start on the date when the money is due and payable. ${ }^{162}$ However, arbitrators have allowed for a period of time for

152. Id. at 72 .

153. Id.

154. Id. at 77 .

155. Id. at 80 .

156. $I d$.

157. See, e.g., New Orleans Saints v. Gumina (2002) (Wittenberg, Arb.).

158. See, e.g., Moore v. Tampa Bay Buccaneers \& Chicago Bears (1983) (Luskin, Arb.); Davis v. Arizona Cardinals (1996) (Kagel, Arb.); Smith v. Los Angeles Raiders (1995) (Jones, Arb.).

159. See, e.g., Bono v. Minnesota Vikings (1989) (Kasher, Arb.); Davis v. Arizona Cardinals (1996) (Kagel, Arb.); Smith v. Los Angeles Raiders (1995) (Jones, Arb.).

160. NFL CBA, supra note 1, at Art. XII.

161. Id. Art. IX.

162. See, e.g., Bono v. Minnesota Vikings (1989) (Kasher, Arb.); Smith v. Los Angeles Raiders (1995) (Jones, Arb.). 
collection attempts. ${ }^{163}$ For example, in Davis v. Arizona Cardinals, the player and his agent informally attempted to obtain money they claimed the kicker had earned during the 1994 season for months before finally sending a letter demanding payment within five days. ${ }^{164}$ Arbitrator Kagel held the Cardinals' failure to respond to this final demand letter was the "occurrence" that started the clock. ${ }^{165}$

Arbitrators also have allowed for time for the party to receive payment. ${ }^{166}$ In Moore v. Tampa Bay Buccaneers and Chicago Bears the player claimed one of his prior two teams owed him injury protection payments. ${ }^{167}$ Arbitrator Luskin held the "occurrence" was the failure of the teams to make the first injury protection payment. ${ }^{168}$ Since the payment was not due until the date of the first 1978 regular season game, that day was when the clock began to toll. ${ }^{169}$ The player had a right to wait a "normal period of time" to see if the team would pay the benefits due. ${ }^{170}$

However, this grace period is not guaranteed. ${ }^{171}$ In Los Angeles Rams $v$. Busik the team inadvertently paid its ex-linebacker injury protection benefits that he had waived as part of a settlement agreement. ${ }^{172}$ After discovering the errant payment, the Rams contacted Busik and his attorney numerous times during 1988 to negotiate repayment. ${ }^{173}$ After nine months of failed attempts to recoup the money, the Rams finally initiated a grievance. ${ }^{174}$ Arbitrator Kagel held the grievance was untimely because although "parties are encouraged to negotiate settlement of a grievance, such effort does not excuse" a late filing in violation of the NFL CBA. ${ }^{175}$ This holding is at odds with those previously discussed. Because arbitrators are not bound by decisions in

163. See, e.g., Bono v. Minnesota Vikings (1989) (Kasher, Arb.); Smith v. Los Angeles Raiders (1995) (Jones, Arb.); Davis v. Arizona Cardinals (1996) (Kagel, Arb.).

164. Davis v. Arizona Cardinals (1996) (Kagel, Arb.), at 20. It is also worth noting that Davis testified during his grievance hearing that during his informal attempts to collect the bonus money the Cardinals repeatedly told him they would work it out, and the team did not refute such testimony.

165. Id.

166. Moore v. Tampa Bay Buccaneers \& Chicago Bears at 13 (1983) (Luskin, Arb.).

167. Id.

168. Id.

169. Id.

170. Id.

171. Los Angeles Rams v. Busik (1992) (Kagel, Arb.).

172. Id. at $4-5$.

173. Id.

174. Id. at 8 .

175. Id. at 15 . 
other arbitrations, the parties may not always know in these instances what an arbitrator will hold to be the "occurrence" and thus, not know when the clock has started.

\section{CONCLUSION}

The timeliness provisions of the NFL CBA should be strictly construed so as to effectuate the intent of the parties to the agreement. It has long been United States federal policy to settle labor disputes through collective bargaining and the grievance process. Arbitration is the preferred forum for those disputes, and the provisions set forth in the collective bargaining agreement govern it. Procedural provisions of agreements are extremely important and should not be ignored. Time limits on when parties may institute grievances are examples of such provisions. They have historically played an important role in assuring the fair judgment of rights.

Fairness is one of the main reasons why the NFL CBA includes time limits in its grievance provisions. Time limits have always been a part of the NFL's grievance procedures, and both the players and management are extremely aware of their existence. The timely processing of grievances ensures a level playing field for both parties. ${ }^{176}$ If a team could process grievances at its leisure, "it is reasonable to assume such matters might be set aside for what might be considered more pressing or immediate problems and thus, delay in attending to the aggrieved complaint."177 Similarly, "if a grievant ... could pick and choose when it wished to progress a grievance, a club could never be sure of its liabilities on any reasonable period of time." 178 The same rationale would apply if a team were the grievant.

Although a collective bargaining agreement sets forth specific deadlines for the parties to follow, situations inevitably arise that question the strict enforcement of the deadlines. For the most part, arbitrators in those situations have strictly enforced the limits. They do not allow the timeliness provisions to take a back seat to the merits. Ignorance, lack of prejudicial effect, and pursuing other legal recourse are no excuse for untimely claims. Timeliness is even important if the NFL CBA has expired.

The only gray areas are when to start the clock and what event gave rise to the grievance. In those situations arbitrators have been careful to attempt to effectuate the parties' intent by determining what is reasonable given the

176. Peterson v. Tampa Bay Buccaneers at 19 (1978) (Searce, Arb.).

177. Id.

178. Id. 
circumstances. However, the only way they can be sure to follow the true intent of the parties is to strictly construe the time limits found in the grievance procedures of the NFL CBA.

Therefore, when faced with a questionable situation the arbitrators should err on the side of forcing the parties to file their claims in the specified time, without excuse. Only then can an arbitrator be sure to give full credit to the nature of those provisions. Time limits are part of the bargain, they serve a valid purpose, and they should be enforced because, in the end, that is most equitable for all parties involved.

\section{ABOUT THE AUTHOR}

AARON J. SOBASKI is an Associate with the law firm of Sheppard, Mullin, Richter \& Hampton LLP, in San Francisco, California. He received his J.D. in 2003 from the University of California - Hastings College of the Law, in San Francisco, California and his B.A. in 1998 from Northwestern University in Evanston, Illinois.

\section{REFERENCES}

Bell v. Morrison, 26 U.S. 351 (1828).

Board of Regents v. Tomanio, 446 U.S. 478 (1980).

Bono v. Minnesota Vikings (1989) (Kasher, Arb.).

Brown v. Los Angeles Raiders (1995) (Volz, Arb.).

Campbell v. Haverhill, 155 U.S. 610 (1895).

Churchman v. San Francisco 49ers (1985) (Fisher, Arb.).

Clementson v. Williams, 12 U.S. 72 (1814).

Collective Bargaining Agreement between County of Marin and Teamster Union, Local 856. (July 11, 1999 - July 3, 2004).

Collective Bargaining Agreement between Union of American Physicians and Dentists (Unit 11-AA) and the City and County of San Francisco. (July 1, 2001 - June 30, 2003).

Craver, Charles B. (1990). Symposium on labor arbitration thirty years after the Steelworkers Trilogy: Labor arbitration as a continuation of the collective bargaining process. Chicago Kent Law Review, 66, 571-629.

Davis v. Arizona Cardinals (1996) (Kagel, Arb.). 
Developments in the law- Statutes of limitations. (1950). Harvard Law Review, 63, 1177-1269.

Dryer v. Los Angeles Rams, 40 Cal. 3d 406 (1985).

Dryer v. Los Angeles Rams (1988) (Kagel, Arb.).

John Wiley \& Sons, Inc. v. Livingston, 376 U.S. 543 (1964).

Joyce v. L.A. Rams (1980) (Stark, Arb.).

Los Angeles Rams v. Busik (1992) (Kagel, Arb.).

Lyons v. Green Bay Packers (1980) (Stark, Arb.).

Moore v. Tampa Bay Buccaneers \& Chicago Bears (1983) (Luskin, Arb.).

National Football League Collective Bargaining Agreement (1977).

National Football League. (1982). Collective Bargaining Agreement.

National Football League. (1993-2000). Collective Bargaining Agreement.

National Football League. (2002-2008). Collective Bargaining Agreement.

National Football League. (1988). Constitution \& Bylaws.

National Football League Players Association. (n.d.). Frequently asked questions. (n.d.). Retrieved August 11, 2005, from http://www.nflpa.org:3005/media/ main. asp? subPage=FAQ.

National Football League Players Association. (1995). Playbook.

National Labor Relations Act, 29 U.S.C. $\S \S 151$, et. seq. (2002).

New Orleans Saints v. Gumina (2002) (Wittenberg, Arb.).

Nolde Bros. Inc. v. Local No. 358, 430 U.S. 243 (1976).

Pacific Coast Longshore Contract Document between the International Longshore and Warehouse Union and the Pacific Maritime Association. (July 1, 1999 - July 1, 2002).

Peterson v. Tampa Bay Buccaneers (1978) (Searce, Arb.).

Republic Steel v. Maddox, 379 U.S. 650 (1965).

Riddlesbarger v. Hartford Ins. Co., 74 U.S. 386 (1868).

Ridley v. Los Angeles Raiders (1996) (Stark, Arb.).

Smith v. Los Angeles Raiders (1995) (Jones, Arb.).

Stadium Financing and Franchise Relocation Act of 1999: Hearing on S. 952 Before the Senate Comm. on the Judiciary, 106th Cong. (June 22, 1999) (testimony of Gene Upshaw, Executive Director of the National Football League Players Association). 
Steelworkers v. Warrior \& Gulf Navigation Co., 363 U.S. 574 (1960).

Steelworkers v. Enterprise Wheel, 363 U.S. 593 (1960).

United States. v. Kubrick, 444 U.S. 111 (1979).

Vaca et al v. Sipes, 386 US 171 (1967)

Welborne v. Minnesota Vikings (1995) (Starks, Arb.).

Wood v. Carpenter, 101 U.S. 135 (1879). 